\title{
PENINGKATAN EFISIENSI ENERGI KIPAS SIRKULASI UDARA DI PANEL LISTRIK MELALUI PENGATURAN KECEPATAN
}

\author{
Dista Yoel Tadeus, Fakhruddin Mangkusasmito \\ Program Studi STr. Teknik Listrik Industri, Sekolah Vokasi, Universitas Diponegoro \\ Jl. Prof. Soedarto, SH, Kampus Undip Tembalang, Semarang, Indonesia 50275
}

\begin{abstract}
Internal temperature of electric panel practically depend on the amount of power dissipation generated by the panel components and the outside temperature. If this equilibrium is not maintained then the internal temperature can increase too high beyond the working temperature limit for components so as to shorten the life of panel components. Generally, there are two fans installed to circulate the air inside the panel that operates at fixed speed. In order to improve fan energy efficiency, it is necessary to add a control system that can adjust the fan speed based on actual panel internal temperature. Efforts to increase energy efficiency are realized using cheap hardware and easily available on the market, the ATMEGA 8535 microcontroller and LM 35 temperature sensor. The fan speed is normalized in percent units and expressed virtually using the Pulse Width Modulation $(P W M)$ signal value calculated by the proportional control algorithm inside the controller. The experimental results show that the PWM value can vary with actual panel internal temperature. Using the time constant temperature asumption $k_{1}=0.2, k_{2}=0.4, k_{3}=0.2, k_{4}=0.2$ and experimental data, it was shown by calculations that there was an increase in energy efficiency by $40.8 \%$.
\end{abstract}

Keywords: Electric Panel; Internal Panel Temperature; Fan Speed Control

\section{PENDAHULUAN}

Saat beroperasi, panel listrik menghasilkan panas yang dapat meningkatkan temperatur ruangan di dalam panel. Kondisi lingkungan yang bervariasi menyebabkan profil temperatur ruang panel juga bervariasi [1]. Temperatur ruang panel dapat berubah menyesuaikan besar disipasi daya yang dihasilkan oleh komponen panel dan temperatur di luar panel $[2,3]$. Bila kesetimbangan ini tidak dijaga maka temperatur ruang dapat meningkat terlalu tinggi melampaui batas temperatur kerja komponen sehingga dapat memperpendek umur komponen panel.

Untuk mengatasi persoalan tersebut, umumnya di dalam panel listrik dipasang dua buah kipas untuk mensirkulasi udara di dalam panel, satu kipas untuk menghisap udara dari lingkungan dan satu kipas untuk membuang udara panas ke lingkungan. Kedua kipas tersebut biasanya ditempatkan di sisi kanan dan kiri badan panel. Kipas beroperasi pada kecepatan tetap yaitu pada kecepatan nominalnya.

Oleh karena temperatur ruang panel dapat berubah secara dinamis maka idealnya kecepatan kipas juga harus dapat berubah mengikuti nilai temperatur. Hal ini bertujuan untuk meningkatkan efisiensi konsumsi energi kipas, karena energi kipas sebanding dengan kecepatannya. Pada saat yang bersamaan juga tetap mengupayakan regulasi temperatur ruang panel di rentang yang aman [4]. Penelitian tentang pengaturan kecepatan kipas untuk peralatan kondenser uap berpendingin udara telah dilakukan untuk menghemat penggunaan energi menggunakan metode kontrol closed-loop [5]. Pengaturan kecepatan kipas diaplikasikan pada Open cathode PEM fuel cell (OC-PEMFC) untuk mengetahui efek kecepatan kipas terhadap pembebanan fuel cell yang berbeda-beda [6]. Sistem pengaturan kecepatan kipas berbasis kontroler proportional-integral-derivatif (PID) dikembangkan untuk meminimalkan konsumsi energi peralatan heating, ventilating and air-conditioning (HVAC), kecepatan kipas sebagai variabel umpan balik diprediksi menggunakan metode adaptif inferensi fuzzy $[7,8]$.

Artikel ini memaparkan suatu upaya peningkatan efisiensi energi kipas sirkulasi di panel listrik dengan cara melakukan pengaturan kecepatan kipas menggunakan algoritma kontroler proporsional. Adapun perangkat keras utama yang digunakan berupa mikrokontroler dan sensor temperatur. Kecepatan kipas dinormalisasi dalam satuan persen dan dinyatakan secara virtual menggunakan nilai sinyal Pulse Width Modulation (PWM) yang dihasilkan oleh kontroler. Besar peningkatan efisiensi dihitung menggunakan data hasil percobaan dan asumsi pada nilai konstanta waktu temperatur.

\section{METODE PENELITIAN}

Diagram blok sistem kontrol secara keseluruhan ditunjukkan oleh Gambar 1 dan diagram blok kontrol proporsional ditunjukkan oleh Gambar 2. Kontroler proposional memiliki keluaran yang sebanding/proposional dengan besarnya sinyal kesalahan (selisih antara besaran yang diinginkan dengan harga aktualnya).

Secara lebih sederhana lagi dapat dikatakan, bahwa keluaran kontroler proporsional merupakan perkalian antara konstanta proporsional dengan masukannya. 


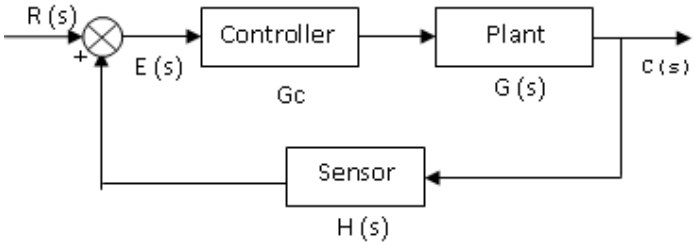

Gambar 1. Diagram blok sistem kontrol lup tertutup

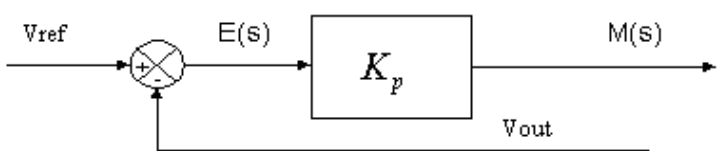

Gambar 2. Diagram blok kontroler proporsional

Perubahan pada sinyal masukan akan segera menyebabkan sistem secara langsung mengubah keluarannya dengan perbandingan bergantung pada konstanta pengalinya. Kontroler proporsional memiliki hubungan antara sinyal kontrol (control signal) dengan sinyal penggerak kesalahan (error), dirumuskan sebagai berikut:

$$
m(t)=K_{p} \cdot e(t)
$$

dimana:

$\mathrm{m}(\mathrm{t})$ : Sinyal kontrol (control signal)

$\mathrm{Kp}$ : Konstanta penguatan dari kontroler proporsional e(t) : Sinyal kesalahan penggerak (error signal) dalam time domain

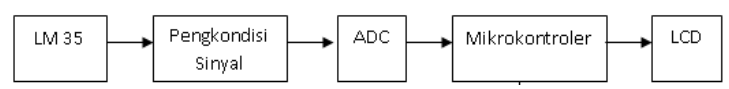

Gambar 3. Diagram aliran sinyal perangkat keras

Gambar 3 menunjukkan diagram blok aliran sinyal perangkat keras. LM 35 menghasilkan tegangan yang proporsional dengan temperatur. LM 35 merupakan salah satu sensor analog yang ekonomis dan mudah didapatkan, memiliki fitur-fitur antara lain: dikalibrasi langsung dalam celcius; memiliki factor skala linear $+10.0 \mathrm{mV} /{ }^{\circ} \mathrm{C}$; jangkauan maksimal suhu antara $-55^{\circ} \mathrm{C}$ sampai $+150^{\circ} \mathrm{C}$; cocok untuk aplikasi jarak jauh; harga yang cukup murah; bekerja pada tegangan catu 4 sampai 30 Volt; memiliki arus drain kurang dari $60 \mathrm{uA}$; pemanasan sendiri yang lambat (low self - heating), $0,08^{\circ} \mathrm{C}$ di udara diam; dan memiliki impedansi keluaran yang kecil, 0,1 W untuk beban $1 \mathrm{~mA}$. Gambar 4 menunjukkan rangkaian dasar LM 35.

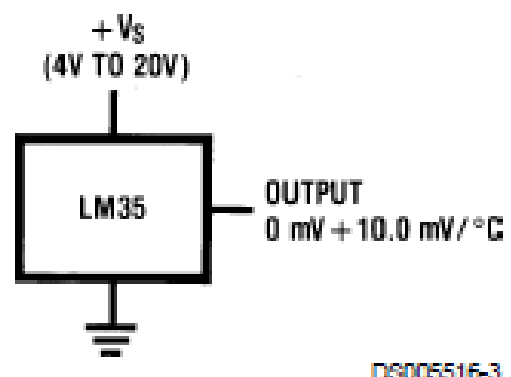

Gambar 4. Rangkaian dasar LM35
Tegangan dari LM 35 selanjutnya dikuatkan oleh rangkaian pengkondisi sinyal sehingga diperoleh tegangan yang lebih besar. Penguatan tegangan ini diatur melalui besar Ri dan $\mathrm{Rf}$ yang sesuai. Besar penguatan dibuat 3.33 untuk memaksimalkan rentang pengukuran LM 35 dan rentang tegangan ADC 0-5V. Gambar 5 menunjukkan rangkaian pengkondisi sinyal menggunakan penguat Op-Amp non-inverting.

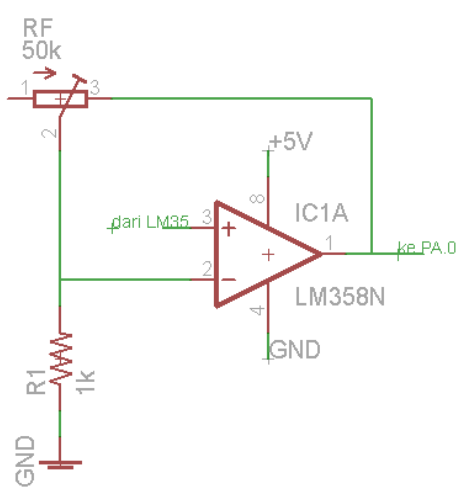

Gambar 5. Rangkaian pengkondisi sinyal

Tegangan tersebut lalu dikonversi menjadi data digital oleh Analog to digital Converter (ADC) internal mikrokontroler untuk dapat dihitung dalam algoritma kontrol yang telah ditanamkan di mikrokontroler. Gambar 6 menunjukkan rangkaian minimum dari mikrokontroler ATMEGA 8535.

Adapun perhitungan untuk mendapatkan nilai temperatur dari data digital ADC menggunakan persamaan (2)

$$
\begin{gathered}
T=\frac{\text { resolusi } A D C}{\text { resolusi } L M 35 \times \text { penguatan }} x \text { data digital } A D C \\
\text { resolusi } A D C=\frac{5 V}{2^{8}-1}=19.6
\end{gathered}
$$

Contoh:

dari pengukuran didapatkan data ADC sebesar 200, resolusi ADC 19.6, resolusi LM $3510 \mathrm{mV}$, dan penguatan 3.33 , maka

$T=\frac{19.6}{10 \times 3.33} \times 50$

$T=29.42{ }^{\circ} \mathrm{C}$

Algoritma kontroler proporsional dibuat secara scheduling yaitu akan aktif dalam rentang temperatur $30^{\circ} \mathrm{C}$ sampai $38^{\circ} \mathrm{C}$. Di bawah $30^{\circ} \mathrm{C}$ PWM akan nol (kipas mati) dan di atas $38^{\circ} \mathrm{C}$ PWM akan 100 persen (kecepatan kipas maksimal). Nilai temperatur yang diukur oleh sensor dan sinyal PWM hasil perhitungan ditampilkan oleh Liquid Crystal Display (LCD). M1632 merupakan modul dot-matrix tampilan kristal cair (LCD) dengan tampilan $16 \times 2$ baris dengan konsumsi daya rendah. Modul LCD ini telah dilengkapi dengan mikrokontroller yang didesain khusus untuk mengendalikan LCD, berfungsi sebagai pengatur (system controller) dan penghasil karakter. Gambar 7 menunjukkan 
rangkaian LCD 16x2, sedangkan Gambar 8 menunjukkan konfigurasi pin LCD.

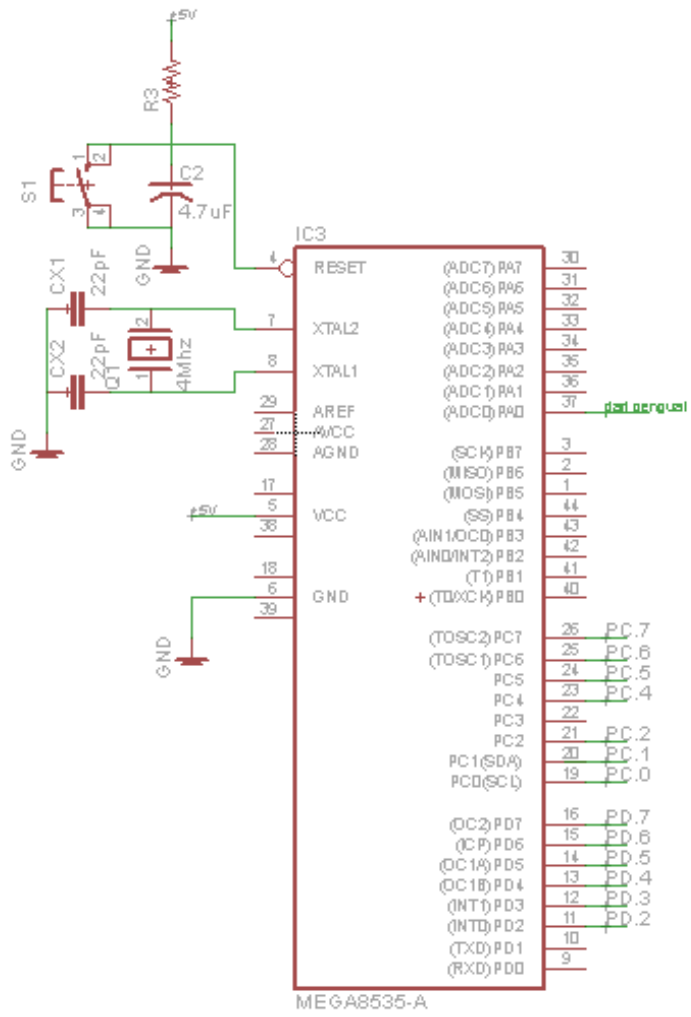

Gambar 6 Sistem minimum ATMEGA 8535

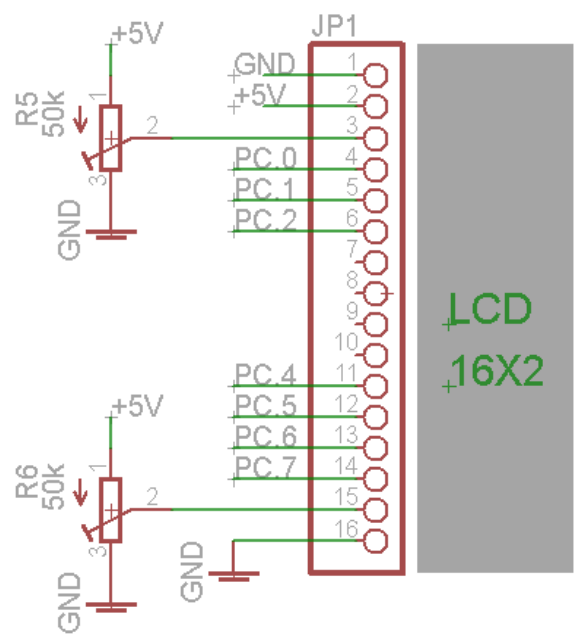

Gambar 7. Rangkaian LCD 16x2

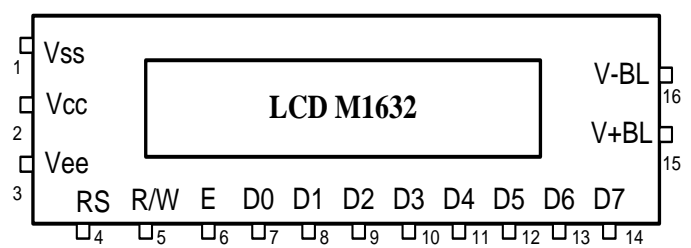

Gambar 8. Konfigurasi kaki LCD M1632

\section{HASIL DAN PEMBAHASAN}

Tabel 1 menunjukkan karakteristik keluaran LM 35 yang dibandingkan dengan pembacaan dari termometer raksa. Tampak bahwa error maksimal adalah $1.3{ }^{\circ} \mathrm{C}$ pada rentang $0^{\circ} \mathrm{C}$ hingga $50^{\circ} \mathrm{C}$. Gambar 7 menunjukkan grafik tegangan keluaran LM 35 yang terlihat cukup linier.

Tabel 1. Perbandingan LM 35 dengan termometer raksa

\begin{tabular}{cccc}
\hline $\begin{array}{c}\text { Suhu } \\
\text { Termomete } \\
\text { r }\left({ }^{\circ} \mathbf{C}\right)\end{array}$ & $\begin{array}{c}\text { Teganga } \\
\text { n } \\
\text { Keluara } \\
\text { n LM 35 } \\
(\mathbf{V})\end{array}$ & $\begin{array}{c}\text { Konversi } \\
\text { Tegangan ke } \\
\text { Suhu dari } \\
\text { LM 35 }\left({ }^{\circ} \mathbf{C}\right)\end{array}$ & $\begin{array}{c}\text { Erro } \\
\mathbf{r} \\
\left({ }^{\circ} \mathbf{C}\right)\end{array}$ \\
\hline 1 & 0.012 & 1.2 & 0.2 \\
5 & 0.058 & 5.8 & 0.8 \\
10 & 0.113 & 11.3 & 1.3 \\
15 & 0.16 & 16 & 1 \\
20 & 0.199 & 19.9 & -0.1 \\
25 & 0.241 & 24.1 & -0.9 \\
30 & 0.294 & 29.4 & -0.6 \\
35 & 0.346 & 34.6 & -0.4 \\
40 & 0.393 & 39.3 & -0.7 \\
45 & 0.441 & 44.1 & -0.9 \\
50 & 0.488 & 48.8 & -1.2 \\
\hline
\end{tabular}

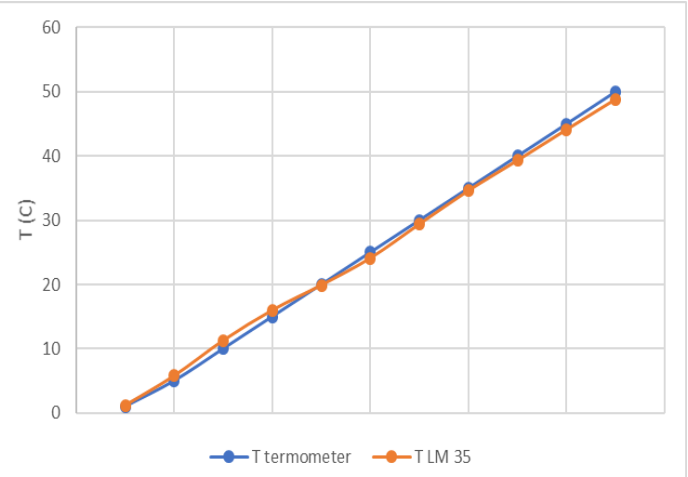

Gambar 7. Grafik tegangan keluaran LM 35

Tabel 2 menunjukkan hasil pengujian algoritma kontrol proporsional yang telah diimplementasikan dengan metode scheduling. Tampak bahwa saat temperatur di bawah $30{ }^{\circ} \mathrm{C}$ nilai $\mathrm{PWM}=0$ (kipas mati), saat temperatur $30{ }^{\circ} \mathrm{C}$ hingga $38{ }^{0} \mathrm{C}$ nilai PWM bervariasi secara proporsional mengikuti nilai temperatur, sedangkan saat temperatur di atas $38{ }^{\circ} \mathrm{C}$ nilai $\mathrm{PWM}=100 \%$ (kecepatan kipas maksimal). Hasil tersebut menunjukkan bahwa sistem kontrol mampu melakukan tugasnya dengan baik sehingga pengaturan kecepatan kipas sesuai temperatur dapat dicapai.

Nilai PWM yang dihasilkan secara virtual sebanding dengan konsumsi energi kipas. Pada akhirnya secara praktis, konsumsi energi kipas di panel listrik dapat dioptimalkan sesuai dengan kondisi temperatur di dalam ruang panel. Tabel 2 juga menunjukkan selisih temperatur perhitungan dengan 
temperatur yang dibaca oleh LM 35 memiliki nilai maksimal $0.5{ }^{\circ} \mathrm{C}$ pada rentang pengujian tersebut.

Tabel 2. Hasil pengujian algoritma kontrol proporsional

\begin{tabular}{|c|c|c|c|c|}
\hline $\begin{array}{c}\text { Tem } \\
\text { p } \\
\text { LM } \\
35 \\
\left({ }^{0} \mathrm{C}\right) \\
\end{array}$ & $\begin{array}{c}\text { Data } \\
\text { digita } \\
\text { l } \\
\text { ADC }\end{array}$ & $\begin{array}{c}\text { Temp } \\
\text { Hasil } \\
\text { Perhitung } \\
\text { an } \\
\left({ }^{\circ} \mathrm{C}\right) \\
\end{array}$ & $\begin{array}{c}\text { Error } \\
\text { Temp } \\
\text { Perhitung } \\
\text { an } \\
\left({ }^{\circ} \mathrm{C}\right) \\
\end{array}$ & $\begin{array}{c}\text { PWM } \\
(\%)\end{array}$ \\
\hline 1.2 & 2 & 1.2 & 0 & 0 \\
\hline 5.8 & 10 & 5.9 & -0.1 & 0 \\
\hline 11.3 & 19 & 11.2 & 0.1 & 0 \\
\hline 16 & 27 & 15.9 & 0.1 & 0 \\
\hline 19.9 & 34 & 20 & -0.1 & 0 \\
\hline 24.1 & 41 & 24.1 & 0 & 0 \\
\hline 29.4 & 50 & 29.4 & 0 & 0 \\
\hline 32.2 & 54 & 31.8 & 0.4 & 39 \\
\hline 34.6 & 58 & 34.1 & 0.5 & 64 \\
\hline 36.4 & 61 & 35.9 & 0.5 & 81 \\
\hline 37.8 & 64 & 37.7 & 0.1 & 95 \\
\hline 39.3 & 66 & 38.8 & 0.5 & 100 \\
\hline 44.1 & 74 & 43.6 & 0.5 & 100 \\
\hline 48.8 & 82 & 48.3 & 0.5 & 100 \\
\hline
\end{tabular}

Nilai PWM hasil perhitungan algoritma kontrol dapat digunakan untuk menghitung seberapa besar peningkatan efisiensi energi yang didapat. Bila diasumsikan dalam satu jam temperatur ruang panel mengalami empat kali perubahan nilai temperatur yaitu $T_{1}=29.4^{\circ} \mathrm{C} \rightarrow T_{2}=36.4^{0} \mathrm{C} \rightarrow T_{3}=37.8^{0} \mathrm{C} \rightarrow$ $T_{4}=32.2^{\circ} \mathrm{C}$, dengan mendefinisikan $k_{1}, k_{2}, k_{3}, k_{4}$ sebagai konstanta waktu temperatur di mana,

$$
k_{1}+k_{2}+k_{3}+k_{4}=1
$$

dan $\rho_{T_{n}}$ sebagai nilai PWM yang dihasilkan saat temperatur $T_{n}$, maka total konsumsi energi kipas tiap jam yang dinormalisasi dalam persen akan sebanding dengan

$$
E_{h}=k_{1} \rho_{T_{1}}+k_{2} \rho_{T_{2}}+k_{3} \rho_{T_{3}}+k_{4} \rho_{T_{4}}
$$

Bila $k_{1}=0.2, k_{2}=0.4, k_{3}=0.2, k_{4}=0.2$, maka

$E_{h}=0.2 \times 0+0.4 \times 81+0.2 \times 95+0.2 \times 39$

$E_{h}=59.2$

Angka tersebut berarti bahwa kipas akan mengkonsumsi energi sebanyak $59.2 \%$ selama satu jam. Jika dibandingkan dengan kipas tanpa pengaturan kecepatan (konsumsi energi $100 \%$ ), maka akan terjadi penurunan konsumsi energi sebesar,

$\eta=\left|\frac{59.2-100}{100}\right| x 100 \%$
$\eta=40.8 \%$ atau dengan kata lain terjadi peningkatan efisiensi energi sebesar $40.8 \%$.

\section{KESIMPULAN}

Upaya peningkatan efisiensi konsumsi energi kipas sirkulasi udara di panel listrik dengan cara mengatur kecepatan kipas yang direalisasikan menggunakan perangkat keras yang murah dan praktis telah ditunjukkan dan mampu memberikan unjuk kerja yang baik. Pengaturan kecepatan kipas yang direalisasi dengan kombinasi perangkat keras dan algoritma kontrol yang sederhana terbukti secara efektif mampu menurunkan konsumsi energi kipas.

Penelitian ini dapat dikembangkan lebih lanjut dengan penggunaan mikrokontroler yang lebih modern seperti Arduino dan sensor temperatur digital guna meminimalkan potensi noise yang umumnya muncul pada sensor analog seperti LM 35 . Perhitungan peningkatan efisiensi energi yang telah dipaparkan secara virtual dapat diverifikasi melalui eksperimen lapangan dengan melakukan pengukuran energi aktual kipas saat beroperasi dalam periode waktu tertentu.

\section{UCAPAN TERIMA KASIH}

Penulis mengucapkan terima kasih kepada laboratorium elektronika Program Studi Teknik Listrik Industri Sekolah Vokasi Universitas Diponegoro.

\section{DAFTAR PUSTAKA}

1. H. Mohamed Kamar, N. B. Kamsah, F. A. Ghaleb, and M. Idrus Alhamid, 2019, Enhancement of thermal comfort in a large space building, Alexandria Eng. J., vol. 58, no. 1, pp. 49-65.

2. J. Wang et al., 2019, Reduced-scale model study on cable heat dissipation and airflow distribution of power cabins, Appl. Therm. Eng., vol. 160, p. 114068.

3. A. Sedaghat and F. de León, 2014, Thermal Analysis of Power Cables in Free Air: Evaluation and Improvement of the IEC Standard Ampacity Calculations, IEEE Trans. Power Deliv., vol. 29, no. 5, pp. 2306-2314.

4. J.-H. Huh and M. J. Brandemuehl, 2008, Optimization of air-conditioning system operating strategies for hot and humid climates, Energy Build., vol. 40, no. 7, pp. 1202-1213.

5. T. Yang, W. Wang, D. Zeng, J. Liu, and C. Cui, 2017, Closed-loop optimization control on fan speed of air-cooled steam condenser units for energy saving and rapid load regulation, Energy, vol. 135, pp. 394-404.

6. T. Zeng et al., 2019, Experimental investigation on the mechanism of variable fan speed control in Open cathode PEM fuel cell, Int. J. Hydrogen Energy, vol. 44, no. 43, pp. 24017-24027.

7. S. Soyguder and H. Alli, 2009, Predicting of fan speed for energy saving in HVAC system based on adaptive network based fuzzy inference 
system, Expert Syst. Appl., vol. 36, no. 4, pp. 8631-8638.

8. Q. Bi et al., 2000, Advanced controller autotuning and its application in HVAC systems, Control Eng. Pract., vol. 8, no. 6, pp. 633-644. 